\title{
PROTO-INDO-EUROPEAN GLOTTALIC STOPS: THE COMPARATIVE EVIDENCE
}

\author{
FREDERIK KORTLAND'T
}

\section{THE TYPOLOGICAL ARGUMENT}

According to the traditional view, the Indo-European protolanguage possessed four series of stops, which correspond to Old Indic $t, t h, d, d h$. The laryngeal theory has made clear that $t h$ does not reflect a unitary phoneme of the proto-language but a sequence of $t$ plus laryngeal. Many scholars have seen that this leaves the reconstructed proto-language with a typologically improbable system of obstruents. Some have concluded that we have to return to the traditional reconstruction, even if the available evidence offers insufficient support for this view. Others have tried to reinterpret the triad $t, d, d h$ in such a way that the reconstructed system becomes more in accordance with typological expectations.

1.1. Holger Pedersen has argued that there are no reliable etymologies which point to PIE. initial $b$ - $(1951: 10-16)$. Since the voiceless labial stop $p$ - is easily lost in several languages (e.g., Celtic, Armenian, Japanese), Pedersen suggests that PIE. $b$ was probably voiceless and weak, while $b h$ may have developed from a voiceless aspirate. He compares the interchange of voiced and voiceless stops with the West Armenian consonant shift.

1.2. Referring to Pedersen's view, André Martinet suggests in a footnote that the PIE. unaspirated voiced stops can be derived from a glottalic series (1953:70). The absence of the labial can be compared with the same phenomenon in Proto-Semitic, for which he reconstructs a glottalic series from which the emphatic obstruents are derived.

1.3. In a neglected article, N.D. Andreev proposes a reconstruction of Proto-Indo-European without voiced obstruents: he reconstructs voiceless fortes, voiceless lenes, and voiceless aspirates, corresponding to traditional $t, d$, $d h$ (1957:7). He explains 
the incompatibility of fortes and aspirates in the root by an assimilation rule.

1.4. Morris Swadesh has suggested that Proto-Indo-European and its neighbors had simple, glottalic, and aspirated stops, and that the difference between voiced and voiceless articulation was a matter of local variation $(1971: 127)$. Since his book was published posthumously, the origin of his view is hard to determine. He remarks that the simple voiced stops of Indo-European are equivalent to the glottalic set in other language families with regard to ancient symbolism (p. 219).

1.5. Gamkrelidze and Ivanov have proposed on the basis of Pedersen's reasoning that the PIE unaspirated voiced stops were glottalic (1972:16). This interpretation allows them to explain the absence of roots with two glottalic stops by a dissimilation rule (1973:153). They also reformulate Grassmann's law as a PIE rule of allophonic variation (1980:30 - 32). This seems to be at variance with the Latin evidence, e.g. fïdo ' $\mathrm{I}$ trust' $<b h e i d h$.

1.6. A similar proposal was put forward by Paul Hopper, who pointed not only to the absence of $b$ and the root structure constraints, but also to the absence of the glottalic stops from inflectional affixes $(1973: 157)$. His view is repeated several times in later articles.

1.7. Jens Rasmussen has proposed to derive traditional $t, d$, $d h$ from earlier $T, t, d$, " $T$ being a cover-symbol for any emphatic stop however phonetically realized (glottalized, pharyngealized, or just stronger)" (1974: 11). The same reconstruction is implied in Illič-Svityč's Nostratic dictionary (1971:147). It is based on the false assumption that glottalic or emphatic stops are stronger than others.

1.8. As early as 1948 André-Georges Haudricourt reached the conclusion that the PIE. unaspirated voiced stops were glottalic and that the original pronunciation was preserved in East Armenian (1975: 267). His argumentation was based on the types of phonetic development attested in the Far East. The negative attitude of Jules Bloch and Jerzy Kuryłowicz toward his view apparently kept him from publishing it.

1.9. In my own exposition I have reinterpreted $t, d, d h$ as fortis, glottalic lenis, and aspirated lenis, respectively (1978: 107). The rephonemicization of either the aspirated or the glottalic stops (or both) as voiced provoked a number of consonantal 
mutations (or mergers) in the separate branches of Indo-European. In Indo-Iranian, Balto-Slavic, Celtic, and Albanian, both $d$ and $d h$ became phonemically voiced. Greek has voiced $d$ and voiceless $d h$, while the converse holds for Germanic, Italic, where $d$ is voiced, and East Armenian, where it is voiceless, have both voiced and voiceless reflexes of $d h$. No rise of phonemically voiced stops took place in Anatolian and Tocharian.

1.10. George Dunkel has rightly pointed out the circularity of the typological argument $(1981: 566)$. If our reconstructions are tailored to typological expectations, they acquire a bias toward the average language type. The more aberrant the structure of the proto-language is, the stronger the bias and the larger the difference between the real and the reconstructed proto-language becomes.

In my view, the discussion suffers from an unfortunate lack of distinction between theory and method. Typological considerations are an extremely useful heuristic device. They can never take the place of the evidence, however. It is therefore remarkable that so little attention has been paid to the comparative evidence, which is abundantly present for those who are ready to see it.

\section{BALTIC}

Latvian preserves the glottalic feature of the unaspirated voiced stops as a glottalic tone on the preceding vowel in originally pretonic syllables, e.g. pệds 'footstep', nuôgs 'naked', Vedic padám, nagnás (Kortlandt 1977). The glottalic tone represents the merger of the glottalic feature with the reflex of the PIE laryngeals. Under the stress, it is preserved in the Žemaitian dialects of Lithuanian (Zinkevičius $1966: 34$ ). The usual view that the glottalic tone is of secondary origin cannot be correct because it does not explain the rise of the glottalization. More probably, the Proto-Baltic acute was a glottal stop which was lost under rising and falling tone movements that originated in the separate languages (Kortlandt 1977:324-328).

It is widely believed that the Proto-Baltic circumflex, like its Greek counterpart, resulted from early contractions while all other ancient long vowels are acute. This view is incorrect. As I have argued elsewhere, the acute is the phonetic reflex of the PIE. laryngeals and the glottalic feature of the unaspirated roiced 
stops, whereas all other ancient long vowels are circumflex (1985a). The latter include the following categories:

(1) Long vowels from contractions, e.g. Lith. gen. sg. algõs 'salary', cf. Gr. $\alpha \lambda \varphi \tilde{\eta} s$.

(2) Lengthened grade vowels in the nom. sg. form of stems

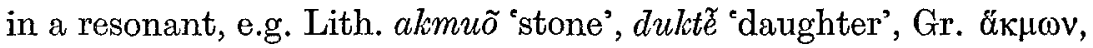

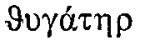

(3) Long vowel preterits, e.g. Lith. ẽme 'took', bẽre 'strewed', $l \tilde{e} k \dot{e}$ 'flew'. The acute of gëre 'drank' reflects the root-final laryngeal, not the long root vowel.

(4) Lith. 3rd person future forms, e.g. duõs 'will give', kalbẽs 'will speak'. Since the long vowel is not shortened in polysyllabic stems, the metatony must be older than Leskien's law (Kortlandt 1975: 86). Assuming that the PIE. laryngeals were lost after lenghtened grade vowels, I connect the metatony in this category with the lengthened grade in the 2nd and 3rd sg. active forms of the Vedic sigmatic aorist injunctive $(1985 \mathrm{~b})$.

(5) Lengthened grado vowels in original root nouns, e.g. Lith. gèlà 'pain', žolẽ 'grass', mèsà 'meat', cf. Slavic žalı, Prussian acc. sg. sālin, Vedic más.

(6) Latvian nom. sg. sàls 'salt' and gùovs 'cow', cf. Gr. $\tilde{\alpha} \lambda \varsigma$, ßoũs, Vedic gáus. Here again, I assume that the laryngeal was lost after a lengthened grade vowel. The expected acute reflex of the laryngeal is found in Lith. sólymas 'brine' (Būga 1959: 584).

(7) Lith. nom. sg. $-\tilde{e}$. In my view, this ending originated from the loss of the laryngeal after a lengthened grade vowel in the nom. sg. form of the root noun which is represented in arklidie 'stable', avìde, 'sheepfold', alùdè 'pub', pelùdè 'chaff store', also žvaigždé "star", Vedic -dhá, Latin -dess, and the Greek passive aorist sufix - $¥ \eta-$.

Thus, I conclude that the PIE laryngeals merged into a glottal stop, which merged with the glottalic feature of the unaspirated voiced obstruents. The Proto-Baltic circumflex is simply the absence of a glottal stop.

\section{SLAVIC}

Baltic and Slavic shared the merger of the PIE. laryngeals with the glottalic feature of the unaspirated voiced stops into a glottal stop. Slavic subsequently lost the glottal stop with compensatory lengthening of a contiguous vowel in pretonic and post-posttonic syllables (Kortlandt 1975:11). Under the stress and in the first 
posttonic syllable the loss of the glottal stop yielded the rise of the new timbre distinctions. As a result, the presence versus absence of the glottal stop is reflected as a difference between short and long reflexes of the ,long" vowels. The difference is usually preserved in Serbo-Croat and has left traces in the other languages. Thus, the short $\ddot{e}, a$ of SCr. jäbuka 'apple', jëdēm 'I eat', pädnëm 'I fall', sjëdnèm 'I sit down', pòbjegnēm 'I flee', jägnje 'lamb', jägoda 'strawberry' reflects the glottalic feature of the following unaspirated voiced obstruent.

Long vowels without a glottal stop were not shortened in Slavic, except under special conditions. Thus, lengthened grade vowels are generally long in Serbo-Croat, e.g. in the following instances:

(1) The word žèrā $v$ 'crane', Czech žeráv, reflects an original nom. sg. form gerōu, ef. Latin grüs (Vaillant 1958: 172). The long vowel is in agreement with the circumflex of Lith. alkmũ 'stone" and Latvian âbuôls 'apple'.

(2) Sigmatic aorist: lst sg. dònijoh next to donèsoh 'brought', and the isolated infinitive rijet (Dubrovnilk) next to rèci i to say' (Vaillant 1966 : 60). Similarly lst sg. mrïjeh, ùmrijeh 'died', klêh, zàklêhh 'swore'.

(3) The tonal alternation between $d \ddot{a} h{ }^{\text {'T }} \mathrm{Tave}$ ' and $d \hat{a}$ 'he gave' is the same as between Lith. dúosiu and duõs 'will give'. I think that it reflects the loss of the laryngeal after a lengthened grade vowel in the aorist injunctive.

(4) Original root nouns, e.g. rïječ 'word', Tocharian B reki, cf. Vedic vák, Latin $v \bar{o} x$, Prussian acc. sg. tārin. Other examples: žâr 'live coals', žára 'nettles', pöz̄ār 'fire', ügār 'fallow', gâr 'soot', čâr 'magic' (Czech čár and čára), nèmār 'negligence', sâm, sáma, sámo 'alone'.

There is additional evidence for the view that the acute was a glottal stop in the fact that it blocked the progressive accent shift (Kortlandt $1975: 14$ ). This constraint has a significant parallel in Avar, where "stress shifted to the second syllable from the first non-pharyngealized one" (Dybo et al. 1978 : 19). It seems to me that the Balto-Slavic evidence suffices to shift the burden of proof onto the adversaries of the glottalic theory.

\section{ARMENIAN}

Shortly after the turn of the century, Pedersen challenged the obtaining views on the Armenian consonant system with the hypothesis that the voiced stops of the classical language were 
aspirated (1906:336-342). This view accepted by Vogt (1938: 327), who discussed the matter in detail in a separate study (1958), and later by Allen (1951: 134) and Benveniste (1959). Garibjan went a step further and surmised that the voiced stops in the western dialects which correspond to the voiceless stops of the classical language constitute an archaism (1959). Agajan has demonstrated that this view cannot be upheld (1960). The very sources from which Vogt and Benveniste drew their inspiration (Adjarian 1909, Allen 1950) permit entirely different conclusions, which are apparently supported by the newly discovered southern dialects (Garibjan 1958). The following analysis will be based on three principles:

(1) A reconstruction of the Common Armenian consonant system on the basis of the modern dialects must logically precede a comparison with material from other Indo-European languages.

(2) If the consonant systems of two related dialects differ in more than a single feature, the historical connection between them involves at least two distinct developments.

(3) If a single uninterrupted central area differs from the peripheral areas with respect to a specific feature, it is probable that the central dialect has innovated.

In order to simplify the discussion, I number the modern dialects in such a way that the first digit reflocts the correspondence with classical $t$ and the second digit the correspondence with classical $d$, both in word-initial position, and that a minimum difference between numbers reflects a minimum difference between dialects in terms of features. In the following list I give, next to the number of each dialect, the reflex of classical $t, d$, th, the corresponding number in the classifications of Vogt (1958) and Garibjan (1959), and a typical representative.

$\begin{array}{lllllcl} & t & d & \text { th } & \text { Vogt } & \text { Garibjan } & \text { examples } \\ 11 & \mathrm{t}=\mathrm{t} & \text { th } & 4 & 7 & \text { Van } \\ 12 & \mathrm{t} & \mathrm{d} & \text { th } & \mathbf{3} & \mathbf{6} & \text { Agulis } \\ 13 & \mathrm{t} & \mathrm{dh} & \text { th } & 1 & 2 & \text { Erevan } \\ 21 & \mathrm{~d} & \mathrm{t} & \text { th } & - & 4 & \text { Sasun } \\ 22 & \mathrm{~d}=\mathrm{d} & \text { th } & 5 \mathrm{a} & 3 & \text { Trabzon } \\ 23 & \mathrm{~d} & \mathrm{dh} & \text { th } & 2 & 1 & \text { Sivas } \\ 20 & \mathrm{~d} & \text { th }=\text { th } & \mathbf{5 b} & 5 & \text { Malatia }\end{array}$


The dialects 11, 22, 20 have apparently come into existence as a result of the neutralization of a phonological opposition. According to Vogt, "il s'agit évidemment d'une simplification secondaire des systèmes centraux" (1958:148), i.e. 13 and 23. Should 11 indeed be derived from 13 ? Since these dialects differ in two features, we have to assume an intermediate stage. If the voicedness was lost earlier than the aspiration, the reflexes of classical $d$ and th must have merged, which is not the case in 11 . If the aspiration was lost earlier than the voicedness, the intermediate stage was identical to the system of dialect 12. But there is no reason why 12 should be derived from 13; both 11 and 13 may actually have to be derived from 12. Geographically, the area which 11 and 12 occupy together forms a semi-circle around the central dialects: Arčeš - Van - Xoy (11) - Agulis - Meghri (12) - Karabagh Kanaker (11) - Lori - Tiflis - Artvin (12). This situation suggests that 13 must be derived from 12 .

The dialects 22 and 20 may indeed be derived from 23, but either of them can also be derived from 21, a dialect which Vogt does not take into account because it is not covered in Adjarian's monograph. Moreover, 22 may be derived from 12 in the same way as 23 can be derived from 13. A choice can only be made by taking into account the geographical distribution of the dialects. Since the position of Trabzon (22) with respect to the Artvin-Tiflis area (12) is the same as that of Little Armenia (23) with respect to Central Armenia (13), it is reasonable to assume that the historical relationship between the Trabzon dialect and its eastern neighbour is the same as that between 23 and 13. The suggestion that 13 must be derived from 12 and the impossibility of deriving 12 from 22 then involve the consequence that the dialects of Trabzon and Little Armenia must be derived from 12 and 13, respectively. If this is correct, the semi-circle discussed above can be extended to Trabzon. Other parts of 22 may have different historical connections. Thus, the isolated dialect of Maraš (22) must probably be derived from the contiguous Hadjin-Zeytun (21). The Malatia-Urfa area (20) is situated within the semi-circle Sasun - Dersim - Hadjin - Beylan - Svedia (21) and must therefore be derived from the latter.

Which distinclive features can be reconstructed for the oldest stage of the apparently archaic dialect 12? I think that the answer 
is provided by Allen's phonetic analysis of an East Armenian dialect (1950). The unaspirated voiceless plosives are glottalic ("ejective") in this dialect, whereas the voiced stops of the classical language are voiceless in initial position. Thus, it is a transitional dialect between 12 and 11, having lost the voicedness of $d$ while retaining the opposition between $d$ and $t$. Actually, the opposition between voiced and voiceless initial stops was restored by the introduction of the loan words beg and boy (Allen 1950:202). The term "potential voiced aspirates" which Allen applies to the reflexes of classical $d$ etc. has given rise to misunderstanding on the part of Benveniste, who inferred the existence of voiced aspirates from the description $(1959: 50)$. In fact, voicing and aspiration are mutually exclusive, the "potential voiced aspirates" being roiced and unaspirated if preceded by a nasal, and lightly aspirated and voiceless in final position after $r$. These are precisely the positions where almost all Armenian dialects show unaspirated voiced and aspirated voiceless plosives, respectively (Pisowicz 1976a: $61-62)$. In initial position, the "potential voiced aspirates" are voiceless. "They are distinguished from the ejectives by having pulmonic as opposed to glottalic plosion, and from the aspirates by the absence of voiceless breath on release. The most notable feature differentiating them from the ejectives, however, is to be found in a following vowel, which is articulated with markedly stronger breath-force and on a lower pitch than is general in other but comparable contexts" (Allen 1950:200). The transfer of the distinctive feature to the following vowel is carried through completely in a part of the dialects 11 (Pisowicz 1976b:215-216). In the original system, the glottalic articulation of the "ejectives" was apparently distinctive. Indeed, 19th. century loan words from Russian showed aspirated plosives in Armenian, e.g. $p^{c} e c^{c}$, manet from peč', moneta (Pisowicz 1976a: 18). Thus, I do not share the usual view that the glottalic articulation of the unaspirated voiceless stops in the Tiflis-Artvin area is due to a Caucasian substratum. It is more probable that the latter simply favored the preservation of a feature which was already present.

The newly discovered dialects 21 seem to corroborate the antiquity of the glottalic articulation. According to Garibjan (1959:85-86) and Pisowicz (1976a:78), these dialects must be derived from the western system 23 . Since 21 and 23 differ in two 
features, we have to assume an intermediate stage. If the voiced- ness was lost earlier than the aspiration, the intermediate stage was identical to 20. If the aspiration was lost earlier than the voicedness, the intermediate stage was identical to 22 . In either case two series would have merged, which is not the case in 21 . I conclude that 21 must be derived from an eastern dialect. Since the geographical position of the southern dialects (21) with respect to the Van area (11) is the same as that of Little Armenia (23) with respect to Central Armenia (13), it is reasonable to assume that the historical relationship between 21 and 11 is the same as that between 23 and 13 . We come to the conclusion that the southern dialects developed from the system of their eastern neighbour at a time when the latter had not yet lost the distinction between the original (glottalic) unaspirated voiceless stops and the ones that originated from the devoicing of the classical voiced stops. Indeed, the dialect of Sarax (between Van and Sasun) distinguishes between two series of unaspirated voiceless stops (Pisowicz 1976a:66) and is in this respect transitional between 11 and 21. We can now connect the two semi-circles discussed above: together they constitute an uninterrupted line of dialects which are archaic with respect to the encircled areas.

We have now established the following relative chronology:

(1) Rise of aspiration in voiced stops $(12 \rightarrow 13)$.

(2) Devoicing of unaspirated roiced stops $(12 \rightarrow 11)$.

(3) Voicing of glottalic stops ( $11 \rightarrow 21,12 \rightarrow 22,13 \rightarrow 23$ ).

(4) Elimination of unaspirated voiceless stops $(21 \rightarrow 22,21 \rightarrow 20)$. The absolute chronology can only be established on the basis of loan words. Since loans from Arabic are subject to shifting while loans from Turkic are not (Agajan 1960:44), we have to date (3) between the 7th and the 10th century. It is possible that (1) was in progress during the classical period, as Džaukjan suggests (1967: 76).

Thus far I have limited the discussion to word-initial plosives because it is the position of maximal contrast in the Armenian dialects. The same type of analysis can be applied to other positions. The generalization of voiced stops after nasals and voiceless aspirates after prefinal $r$ are probably early developments because they have affected the large majority of dialects. Intervocalically, the following types are found: 


$\begin{array}{lrrrl} & t & d & \text { th } & \text { examples } \\ \text { 10a } & \mathrm{t} & \text { th }=\text { th } & \text { Karabagh, Lori } \\ \text { 11a } & \mathrm{t}=\mathrm{t} \text { th } & \text { Van } \\ \text { 12a } & \mathrm{t} & \mathrm{d} \text { th } & \text { Agulis } \\ \text { 20a } & \mathrm{d} & \mathrm{th}=\mathrm{th} & \text { Malatia, Trabzon, Erevan, Tiflis } \\ \text { 21a } & \mathrm{d} & \mathrm{t} & \text { th } & \text { Sasun } \\ \text { 23a } & \mathrm{d} & \mathrm{dh} & \text { th } & \text { Sivas }\end{array}$

The areas $12 \mathrm{a}$ and $23 \mathrm{a}$ are small islands within $10 \mathrm{a}$ and $20 \mathrm{a}$, respectively, while $11 \mathrm{la}$ and $21 \mathrm{a}$ are considerably smaller than 11 and 21. A large part of the eastern dialects have the western (voiced) reflex of intervocalic $t$ etc. Almost all northern dialects have been subject to the aspiration of intervocalic $d$ etc. Following the principles which have been put forward above, one arrives at the same reconstruction and the same relative chronology as have been established for initial plosives, plus one additional development:

(5) Devoicing of voiced aspirates $(13 a \rightarrow 10 a, 23 a \rightarrow 20 a)$.

The reconstructed Common Armenian obstruent system now appears as follows:

voiced

aspirated plain glottalic

voiceless

th $\quad t$

$d$

The first Armenian consonant shift is seen to consist in the loss of the aspiration of PIE. $d h$, the rephonemicization of lenis PIE. $d$ as voiceless, and the weakening of the occlusion of PIE. $t$.

\section{VEDIC AND AVESTAN}

The Balto-Slavic evidence points to a series of preglottalized voiced obstruents as the earliest reconstructible reflex of the PIE. glottalic stops. Alexander Lubotsky has adduced Indo-Iranian evidence in support of this interpretation (1981:137).

The root of Gr. $\pi$ r $\gamma v 0 \mu$ 'fasten' is represented in the Rgveda as follows: 3rd sg. pápaje 'stiffened', pajrá- 'firm', pakșá- 'wing', pakșin- 'bird', pákşas- 'side', pá́jas- 'frame', päjasyà- 'flank'. The distribution of short and long root vowel can be explained by the assumption that the laryngeal was lost before a glottalic obstruent when the latter was followed by another consonant. 
Lubotsky adduces fourteen roots in laryngeal plus glottalic stop with short root vocalism in Old Indic, five of which have Avestan correspondences with a short root vowel. Thus, Lubotsky's law must be dated to the Indo-Iranian period. The development is understandable if a sequence of laryngeal plus glottalic stop was realized as a glottal stop plus preglottalized voiced obstruent.

\section{SINDHI AND PANJABI}

The hypothesis that the unaspirated voiced stops of old Indic were preglottalized is confirmed by immediate comparative evidence from Sindhi, which has preserved the glottalic articulation. This language has a threefold opposition between voiced stops: the unconditioned reflexes of the $d$ and $d h$ series are glottalic and aspirated, respectively, while dissimilation of the $d h$ series before aspirates of recent origin has given rise to a plain voiced series, e.g. 'g $g \bar{a} h^{u}$ 'bait'<grāsa-, gāa $h^{u}$ 'fodder'<ghāasa-. It can be shown that the glottalic stops are at least older than the loss of the PIE. laryngeals (Kortlandt 1981: $17-18$ ). There is no reason to disclaim their PIE origin. The glottalic articulation cannot be attributed to external influence because the neighbouring languages do not present anything comparable.

The Panjabi material also requires the former existence of preglottalized voiced obstruents at a recent stage. In this language, the voiced aspirates have become voiceless and unaspirated, yielding a low tone on the following vowel, e.g. kòr $\bar{a}$ 'horse', Hindi ghora $\bar{a}$. Since the voiceless aspirates have been preserved as a separate category, the $d h$ series was not phonemically aspirated at the time of the devoicing (Haudricourt 1975:271). It follows that the glottalic stops were preserved at that stage. Moreover, the $d$ series did not lower the tone of a following vowel. This also points to the preservation of the glottalic feature.

\section{GREEK}

The usual reconstruction of the PIE. word for ' $100^{\circ} k^{\prime}$ mitóm does not account for the initial vowel of Gr. Éaróv. The comparison of this vowel with the word for 'one' sem- is at variance with the indeclinability and the syntactic behavior of Ekatóv. The original character of the indeclinability is evident both from the 
preservation of the final nasal in composition and from the absence of a plural form. If the latter had existed at an earlier stage, it would hardly have been replaced with a derivative formation. Thus, I think that the Greek form and its syntax are more archaic than is generally assumed.

The initial vowel of $\varepsilon$ k $\alpha$ tóv can be explained if we start from PIE. dk'mtom and assume that the buccal features of the initial consonant were lost while its glottalic feature merged with the reflex of the PIE laryngeal $H_{1}$ to yield e-, with subsequent adoption of the aspiration from the word for 'one' (Kortlandt 1983: 98). This explanation, which presupposes that $d$ was a glottalic obstruent at the time under consideration, has the additional advantage of accounting for the long vowel in the decades, e.g.

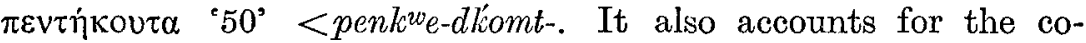
existence of the southern form Eilkoor $<\dot{\varepsilon} F \hat{f}$ kool and the northern

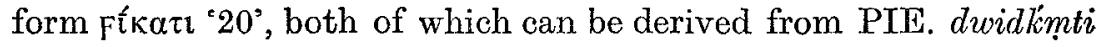
if we assume that partial dissimilation of the initial consonant yielded $H_{1}$-whereas total dissimilation yielded zero. This again presupposes that the glottalic articulation of $d$ had been preserved at the time of dissimilation.

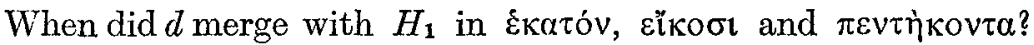

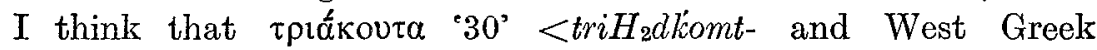

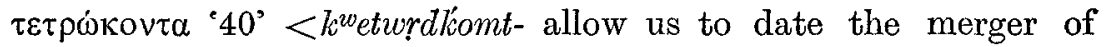
$d$ with the laryngeals to a stage which was posterior to the rise of colored epenthetic vowels, but anterior to the eventual loss of the laryngeals. Since the development of colored epenthetic vowels is specifically Greek, it follows that the PIE glottalic stops were preserved up to a comparatively recent stage.

\section{LATIN}

In Latin we find a long root vowel in äctus 'driven', lëctus 'gathered', where the velar stop belongs to the PIE glottalic series, and a short root vowel in factus 'made', vectus 'carried', where it belongs to the fortis or aspirated series. The Balto-Slavic and Indo-Iranian developments show that the glottalic feature characterized the initial part of the obstruent, whereas the aspiration characterized its final part in view of Bartholomae's law. When voicedness became phonemic, the aspiration in the cluster -ghtwas simply lost, but the glottalic articulation in -gt- was preserved 
as a feature of the preceding vowel. As in the Greek and Balto-Slavic instances cited above, it merged with the reflex of $H_{1}$.

The same development accounts for the long vowel in the

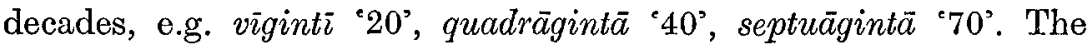
voicing of $k$ to $g$ in these words must be attributed to the preceding nasal in septmalkont- ' $70^{\prime}$ and newndkont- ' $90^{\prime}$ (Thurneysen 1883: 313). This voicing rule was Italo-Celtic, as is clear from Old Irish sechtmogo ' 70 ', as oppcsed to cethorcho ' 40 '. The quantitative difference between Latin viginti and Old-Irish fiche ' 20 ', like the difference between Latin rèctus 'straight' and Old Irish recht 'law', shows that the loss of the glottalic articulation was posterior to the disintegration of Italo-Celtic.

The glottalic feature was lost after a consonant, e.g. in the nasal presents stringo 'tighten', pingō 'paint' <-g-, which merged with fingo 'touch', mingo 'urinate' <-gh-. This accounts for the absence of a long vowel in strictus, pictus, which adopted the vocalism of fictus, mictus. The glottalic feature was apparently absorbed by the preceding laryngeal in lassus 'tired' $<l H_{1} d t o s$, just as the laryngeal was absorbed by the following glottalic obstruent in Vedic pajrá- 'firm'. The initial syllable of sedeo 'sit' was prefixed to the form sdtos in -sessus. Thus, the Latin evidence supports the reconstruction of a series of preglottalized obstruents.

\section{GERMANIC}

In his monograph on the West Jutland stød, K. Ringgaard concludes "that the V-stød is only found immediately before the plosives $p, t, k$, and that it is found wherever these stand in an original medial position, following a voiced sound in a stressed syllable. The exceptions to this are certain types of loan-words from a later period" $(1960: 10,195)$. "The $v$-stød is a complete occlusion of the vocal cords, combined with the diaphragm's movement of inhalation", (p. 199), i.e. a full-fledged glottal stop. Ringgaard dates the rise of the West Jutland stød to the 12 th century because it is characteristic of "all then existing. medial plosives". His view that it is a spontaneous innovation of the westernmost dialects of Danish can hardly be called an explanation. Moreover, it does not account for the parallel development of preaspiration in Icelandic.

Preaspiration is found not only in Icelandic, but also in Far- 
oese, Norwegian, and the Gaelic dialects of Scotland. Phonetically, the preceding vowel is cut short and continued as a whisper; a preceding resonant $(m, n, l, r)$ is partly or wholly unvoiced. The distribution of preaspiration in Icelandic is the same as in the Norwegian dialect of Jæren (Oftedal 1947). We can therefore conclude that it is "an example of a feature taken to Iceland by the original settlers" (Chapman 1962:85).

Carl Marstrander has argued that the preaspiration in Scottish Gaelic is due to a Norse substratum (1932:298). He advances the hypothesis that the Norwegian preaspirated stops represent a retention of the clusters $h p, h t, h k$, which developed into geminates elsewhere (p. 302). This theory implies three developments: $t t<h t$ in East Norse, $h t<t t$ in West Norse, and $h t<t$ in West Norse in those positions where the preaspirated stop does not reflect a cluster, e.g. Icelandic epli 'apple', vatn 'water', mikla 'incr ase', hjálpa 'help', verk 'work'. Here the preaspirated stop appears to be the phonetic reflex of a PIE. unaspirated voiced obstruent.

Both the West Jutland stød and the preaspiration receive a natural explanation if we assume that Early Proto-Germanic, like Proto-Balto-Slavic and Proto-Indo-Iranian, possessed a series of preglottalized voiced stops. Devoicing yielded a series of Late Proto-Germanic sequences ${ }^{2} p,{ }^{2} t,{ }^{2} k$, the glottal stop of which was lost under various conditions. Weakening of the gIottal stop in West Norse yielded preaspiration, while its assimilation to the following obstruent gave rise to a series of geminates in East Norse, with the exception of Danish, where the sequences were subject to lenition and the glottal stop was preserved in the western dialects. I wonder if Swedish vecka 'week', droppe 'drop', skepp 'ship' reflect a dialect that escaped the earliest loss of the glottal stop.

One may wonder if preglottalization had been preserved in word-initial position in Late Proto-Germanic. There is positive evidence for this in the West Jutland stød of fattig<fátékr 'poor" $<$ 'few-taking', sytten 'seventeen'.

Apart from the straightforward explanation of the West Jutland stød and the Icelandic preaspiration, the theory advanced here has the advantage of accounting in a principled way for the existence of several layers of gemination, which can now bo viewed as retentions rather than innovations: 
(1) $m p, n t, n k$ yielded $p p, t t, k k$ in the larger part of Scandinavia. The nasal consonant was apparently devoiced by the glottal feature which preceded the stop, and subsequently lost its nasalization.

(2) $k$ yielded $k k$ before $j$ and $w$. Similarly, $t$ yielded $t t$ before $j$ in a limited area, e.g. Swedish sätta 'set'. The development cannot easily be identified with the change of $g$ into $g g$ before $j$ because the latter involves the transformation of a fricative into a stop.

(3) $p, t, k$ yielded $p p, t t, k k$ before $r$ and $l$ in West Germanic. The same development is found sporadically in Scandinavia. Here again, the geminate may have originated from the assimilation of a glottal stop to the following buccal stop.

It is possible that the theory put forward here has certain consequences for the interpretation of the West Germanic material. Firstly, the High German sound shift may have resulted from a lenition of the buccal stops with concomitant oralization of the preceding glottal stop. If this is correct, the glottalization must have been preserved at the time of the shift. Secondly, the absence of aspirated stops from Dutch and Frisian may be due to an early loss of preglottalization in this area. Thirdly, the English glottal stop may be much more ancient than is commonly assumed. It appears that these possibilities merit further consideration.

\section{CONCLUSION}

The Balto-Slavic, Indo-Iranian, Italo-Celtic and Germanic evidence points to the former existence of a series of preglottalized voiced obstruents. This reconstruction is supported by evidence from Greek and Armenian. In the modern languages, glottalization has been preserved in Latvian and Sindhi, and in dialects of Lithuanian, Armenian, and Danish. Most probably, the preglottalized voiced obstruents originated from a common innovation of all Indo-European dialects except Anatolian and Tocharian, where voicedness never became a phonemically relevant feature.

We may now reconsider the typological argumentation cited in the introduction. It will be seen that my own view is closest to the positions held by Andreer and Swadesh: the proto-language had simple fortes, glottalic lenes, and aspirated lenes stops, cor- 
responding to traditional $t, d, d h$. As in modern Icelandic and in the southern dialects of East Armenian, all stops were usually voiceless. This fits in with the absence of a voiced counterpart to the PIE. fricative $s$.

The typological reinterpretation of the obstruent system was based on the poor attestation of the labial stop $b$, the incompatibility of two glottalic stops in the root, and the incompatibility of fortes and aspirates in the root. The latter constraint has a notable parallel in Austronesian (Bradshaw 1979). The absence of initial $b$ - can hardly be explained by the loss of an earlier $p$-, as Pedersen maintained (1951 : 12). I think that the right solution was indicated by R. Thurneysen (1908): $b$ - lost its glottalic feature and merged with $p$-, cf. especially Vedic pibati 'drinks', Old Irish $i b i d$, Armenian ampem (with secondary nasal infix), Latin bibō (with restored reduplication). Medial - $b$ - was preserved, e.g. in Latv. âbuõls 'apple' <abōl-, Lith. obelìs<abel-, Russ. jábloko<abl-, where the ablaut guarantees the PIE. origin of the word.

It has been conjectured that Germanic and Armenian preserve the original voicelessness of the PIE. glottalic stops. I think that this is incorrect. In the case of Germanic, the fact that the glottal feature precedes the buccal stop suggests that the latter was voiced at an earlier stage. In the case of Armenian, its close relationship with Greek, Albanian, Balto-Slavic and Indo-Iranian suggests that the voicelessness is secondary. Thus, I think that the original system was not preserved outside Anatolian and Tocharian. *

\section{FREDERIK KORTLANDT \\ Cobetstraat 24 \\ $N L-2313 K C \quad L E I D E N$ \\ HOLLAND}

\section{REFERENCES}

Adjarian, $\mathbf{H}$.

1909 Classification des dialectes arméniens (Paris: Honoré Champion). Agajan, E. B.

1960 "O genezise armjanskogo konsonantizma", Voprosy Jazylo. znanija 1960/4: 37 - 52.

* A Russian version of this article has appeared in Voprosy Jazykoznanija 1985/4 : 43-53. 
Allen, W. S.

1950 "Notes on the phonetics of an Eastern Armenian speaker", Transactions of the Philological Society 1950: $180-206$.

1951 "Phonetics and comparative linguistics", Archivum Linguisticum 3: $126-136$.

Andreev, N. D.

1957 "Periodizacija istorii indoevropejskogo prajazyka", Voprosy Jazykoznanija 1957/2: 3 - 18.

Benveniste, E.

1959 "Sur la phonétique et la syntaxe de l'arménien classique", Bulletin de la Société de Linguistique de Paris 54: 46 - 68.

Bradshaw, J.

1979 "Obstruent harmony and tonogenesis in Jabêm", Lingua 49: 189 $-205$.

Būga, K.

1959 Rinktiniai raštai II (Vilnius: Valstybinè politinès ir mokslinès literatüros leidykla).

Chapman, K. G.

1962 Icelandic-Norwegian linguistic relationships (Oslo: Universitetsforlaget).

Dunkel, G.

1981 "Typology versus reconstruction", Bono Homini Donum: Essays in Historical Linguistics in Memory of J. Alexander Kerns (Amsterdam: Benjamins), vol. IT, 559 - 569 .

Dybo, V., Nikolayev S., Starostin S.

1978 "A tonological hypothesis on the origin of paradigmatic accent systems", Estonian Papers in Phonetics (Tallinn: Academy of Sciences), $16-20$.

Džaukjan, G. B.

1967 Očerki po istorii dopis'mennogo perioda armjanskogo jazyka (Erevan: AN Arm. SSR).

Gamkrelidze, T. V. \& Ivanov V. V.

1972 "Lingvističeskaja tipologija i rekonstrukcija sistemy indoevropojskix smyčnyx", Konferencija po sravnitel'no-istoričeskoj grammatike indoevropejskix jazykov: Preduaritel'nye materialy (Moskva: Nauka), 15 - 18.

1973 "Sprachtypologie und die Rekonstruktion der gemeinindogerma. nischen Verschlüsse", Phonetica 27: $150-156$.

1980 "Rekonstrukcija sistemy smyčnyx obščeindoevropejskogo jazyka: Glottalizovannye smyčnye v indoevropejskom", Voprosy Jazykoznanija 1980/4: $21-35$.

Garibjan, A. S.

1958 "Novaja gruppa dialektov armjanskogo jazyka"; Voprosy Jazykoznanija 1958/6: 95 - 101 .

1959 "Ob armjanskom konsonantizme", Voprosy Jazykoznanija 1959/5: $81-90$.

Haudricourt, A.- G.

1975 "Les mutations consonantiques (occlusives) en indo-européen", 
Mēlanges linguistiques offerts à Emile Benveniste (Louvain: Peoters), $267-272$.

Hopper, P. J.

1973 "Glottalized and murmured occlusives in Indo-European", Glossa 7: 141 - 166.

Illič-Svityと, V. M.

1971 Opyt sravnenija nostraticestix jazylov: Vvedenie, Sravnitel'nyj slovar' b-K (Moskva: Nauka).

Kortlandt, F.

1975 Slavic accentuation: $A$ study in relative chronology (Lisse: Peter de Ridder).

1977 "Historical laws of Baltic accentuation", Baltistica 13/2: 319 - 330.

1978 "Proto-Indo-European obstruents", Indogermanische Forschungen 83: $107 \cdot 118$.

1981 "Glottalic consonants in Sindhi and Proto-Indo-European", Indo-Iranian Journal 23: 15 - 19.

1983 "Greek numerals and PIE. glottalic consonants", Münchener Studien zur Sprachwissenschaft 42: 97-104.

1985a "Long vowels in Balto-Slavic", Baltistica 21: 112 - 124.

1985b "Archaic ablaut patterns in the Vedic verb", Hoenigswald Felicita. tion Volune, to appear.

Lubotsky, A.

1981 "Gr. pégnumi : Skt. pajrá- and the loss of laryngeals before mediae in Indo-Iranian", Münchener Studien zur Sprachwissenschaft 40: $133-138$.

Marstrander, C. J. S.

1932 “Okklusiver og substrater", Norsk Tidsskrift for Sprogvidenskap 5: $258-314$.

Martinet, A.

1953 "Remarques sur le consonantisme sémitique", Bulletin de la Société de Linguistique de Paris 49: 67 - 78.

Oftedal, M.

1947 “Jærske okklusivar", Norsk Tidsskrift for Sprogvidenskap 14: $229-235$.

Pedersen, $\mathrm{H}$.

1906 "Armenisch und die Nachbarsprachen", Zeitschrift für vergleichende Sprachforschung 39: $334-484$.

1951 "Die gemeinindoeuropäischen und die vorindoeuropäischen Verschlusslaute", Historisk-filologiske Meddelelser 32/5 (København: Munksgaard).

Pisowicz, A.

1976a Le développement du consonantisme arménien (Wroclaw: Polska Akademia Nauk).

1976b "Matériaux pour servir à la recherche du consonantisme arménien", Folia Orientalia 17: 197 - 216.

Rasmussen, J. E.

1974 "Haeretica Indogermanica: A selection of Indo-European and 
pre-Indo-European studies", Historisk-filosofiske Meddelelser $47 / 3$

Ringgaard, $\mathrm{K}$.

(København: Munlisgaard).

1960 Vestjysk stod (Aarhus: Universitetsforlaget).

Swadesh, M.

1971 The origin and diversification of language (Chicago: Aldine-Alhertion).

Thurneysen, R.

1883 "Urspr. $d n$ tn on im lateinischen", Zeitschrift für vergleichende Sprachforschung 26: 301 - 314.

1908 Lecture, reported in Indogermanische Forschungen: Anzeiger 22: 65 .

Vaillant, A.

1958 Grammaire comparée des langues slaves II: Morphologie (Lyon: IAC).

1966 Grammaire comparée des langues slaves III: Le verbe (Paris: Klıncksieck).

Vogt, $H$.

1938 “Arménien et caucasique du sud", Norsk Tidsskrift for Sprog. videnskap 9: 321 - 338 .

1958 "Les occlusives de l'arménien", Norsk Tidsslcrift for Sprogvidenskap 18: $143 \cdot 161$.

Zinkevičius, Z.

1966 Lietuviu dialektologija: Lyginamoji tarmiu fonetilka ir morfologija (Vilnius: Mintis). 